\title{
JURNAL
}

REKAYASA ENERGI DAN MEKANIKA

\section{Perancangan Alat Pembuangan Abu Pada Gasifier Sistem Kontinu Berbahan Bakar Tongkol Jagung}

\author{
Noviyanti Nugraha, M. Pramuda Nugraha Sirodz, Benardino Hadiwijaya \\ Teknik Mesin Institut Teknologi Nasional Bandung, Indonesia \\ Jl. PHH. Mustafa No.23 Bandung 40124 \\ e-mail:n novianti@itenas.ac.id
}

\begin{abstract}
Abstrak
Indonesia membutuhkan energi alternatif yang berpeluang besar untuk dikembangkan pemanfaatannya, salah satunya adalah energi biomassa yang berasal dari jagung. Pada penelitian sebelumnya sudah dirancang dan dibuat sistem gasifikasi kontinu, tetapi masih terdapat kekurangan pada pemisahan abu setelah pembakaran. Tujuan dari penelitian ini adalah untuk merancang sistem pemisah abu pada sistem gasifikasi kontinu sehingga didapatkan spesifikasi dari sistem pemisah abu tersebut. Sistem pemisah abu yang dirancang adalah screw conveyor untuk memisahkan bottom ash dan siklon untuk memisahkan fly ash. Hasil perancangan diperoleh spesifikasi yang dibutuhkan yaitu diameter screw sebesar 6 inci, motor listrik yang digunakan memiliki daya $1 \mathrm{HP}$, putaran screw sebesar 0,31 rpm dan poros screw conveyor sebesar 2 inci. Dengan standar yang sudah diberikan, dengan mengasumsikan diameter body siklon sebesar 0,1 m maka diperoleh seluruh dimensi siklon. Dengan diameter sebesar 0,1 m secara perhitungan didapat efisiensi siklon sebesar 78\% dan secara simulasi menggunakan software ANSYS didapat efisiensi sebesar $80 \%$.
\end{abstract}

Kata kunci: tongkol jagung, gasifikasi, screw conveyor, siklon, ANSYS

\begin{abstract}
Indonesia needs alternative energy that has a great opportunity to be developed its utilization, one of which is biomass energy derived from corn. In previous studies, a continuous gasification system has been designed and built, but there are still deficiencies in the separation of ash after combustion. The purpose of this research is to design an ash separator system in a continuous gasification system so that the specifications of the ash separator system can be obtained. The ash separator system designed is a screw conveyor for separating bottom ash and cyclones for separating fly ash. The design results obtained the required specifications, the screw diameter is 6 inches, the electric motor used has a power of 1 HP, the screw rotation is $0.31 \mathrm{rpm}$ and the screw conveyor shaft is 2 inches. With the standards that have been given, assuming the diameter of the cyclone body is $0.1 \mathrm{~m}$, all the dimensions of the cyclone are obtained. With a diameter of $0.1 \mathrm{~m}$, the calculation is that the cyclone efficiency is $78 \%$ and by simulation using the ANSYS software, the efficiency is $80 \%$.
\end{abstract}

Key words: corn cobs, gasification, screw conveyor, cyclone, ANSYS 


\section{Pendahuluan}

Indonesia memiliki banyak sumber energi alternatif yang berpeluang besar untuk dikembangkan pemanfaatannya, salah satunya adalah energi biomassa yang berasal dari tongkol jagung. Biomassa didefinisikan sebagai bagian dari tumbuhan yang dapat digunakan sebagai bahan bakar padat atau diubah ke dalam bentuk cair atau bentuk gas untuk menghasilkan energi listrik, panas, bahan kimia atau bahan bakar [1].

Dalam proses gasifikasi, biomassa mengalami proses pyrolisis parsial dalam kondisi substoikiometrik dengan jumlah udara dibatasi 1.5-1.8 $\mathrm{kg}$ udara per $\mathrm{kg}$ biomassa [2].

Berbagai jenis biomassa dapat digunakan dalam proses gasifikasi, mulai dari kayu, kertas, tandan kosong kelapa sawit, sekam padi, hingga tongkol jagung [1]. Tongkol jagung merupakan limbah hasil proses pemipilan jagung. Limbah tongkol jagung di Indonesia cukup berlimpah hal ini didukung dari produksi jagung nasional mengalami peningkatan rata-rata 5,39\% setiap tahunnya. Tahun 2016, produksi jagung adalah sebesar 23,2 juta ton atau meningkat cukup signifikan sebesar 18\% dibandingkan tahun 2015 [3].

Limbah tongkol jagung yang memiliki kandungan karbon yang tinggi. Hasil penelitian menunjukkan bahwa untuk mengeringkan 6 ton jagung dari kadar air 32.5\% sampai $13.7 \% \mathrm{bb}$ selama 7 jam diperlukan sekitar $30 \mathrm{~kg}$ tongkol jagung kering per jam [4]. Limbah tongkol jagung ini akan dimanfaatkan menjadi sumber energi melalui proses gasifikasi. Gasifikasi yaitu memanfaatkan syngas (synthetic gas) dari hasil pembakaran biomassa sehingga lebih efisien dan ramah lingkungan dibandingkan dengan pembakaran langsung.

Pada penelitian sebelumnya sudah dirancang dan dibuat sistem gasifikasi kontinu seperti yang diperlihatkan pada gambar 1.

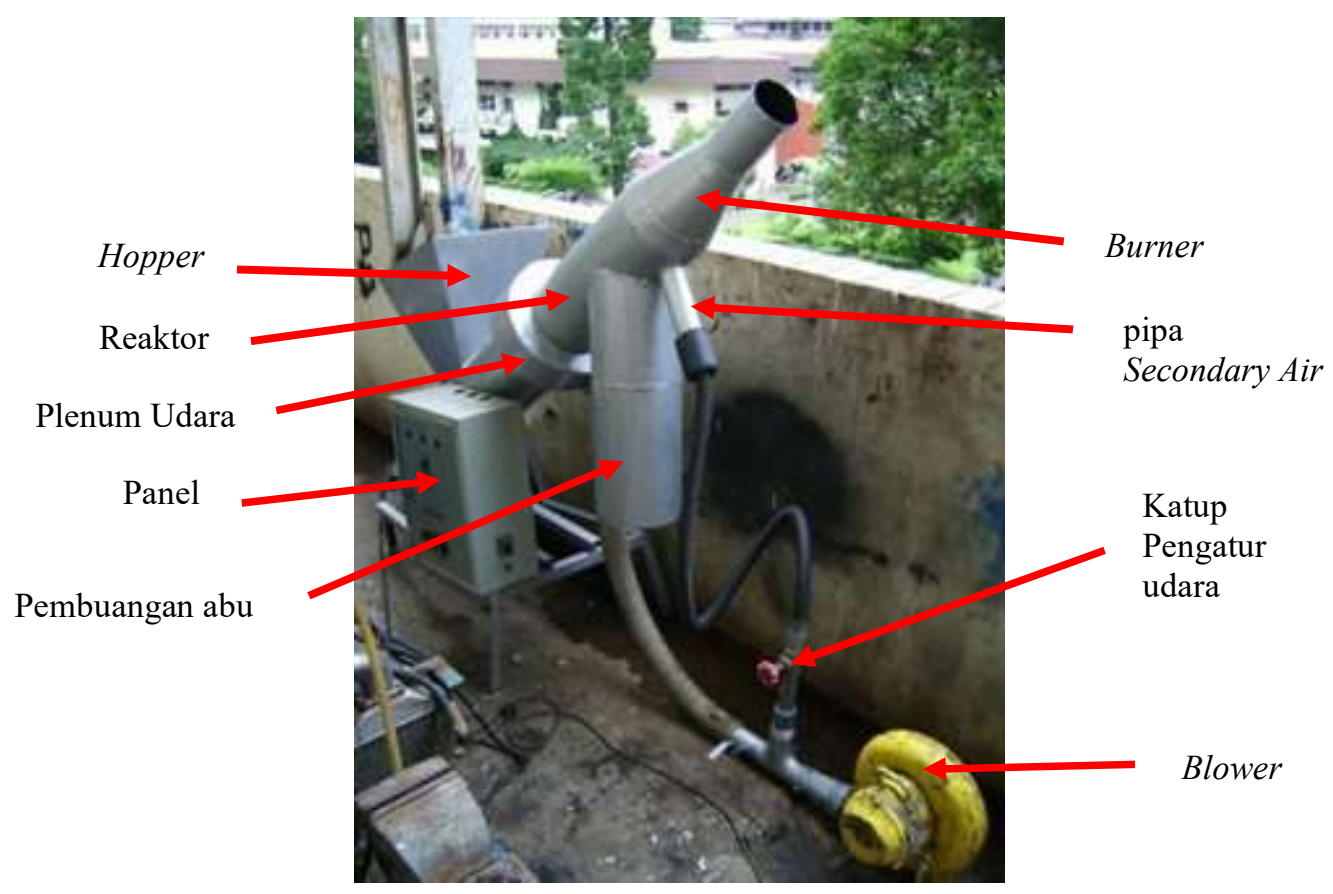

Gambar 1. Alat gasifikasi kontinu pada penelitian sebelumnya

Kelebihan alat ini merupakan alat gasifikasi dengan reaktor jenis inverted downdraft yang dapat bekerja secara kontinu. Prinsip kerja alat tersebut adalah: tongkol jagung dicacah terlebih dahulu menjadi ukuran $5 \mathrm{~mm} \times 5 \mathrm{~mm}$. Setelah motor screw conveyor dinyalakan, tongkol jagung dimasukkan ke dalam hopper. Jika tongkol jagung telah sampai di bagian tengah antara plenum dan bagian pembuangan abu, motor screw conveyor kemudian dimatikan. Reaktor yang berisi tongkol jagung disiram dengan sedikit minyak tanah kemudian dinyalakan menggunakan pemantik. Setelah timbul api, blower dinyalakan dan udara yang masuk ke dalam reaktor diatur [5]. 
Pada alat yang dirancang pada peneltian sebelumnya terdapat kekurangan pada pemisahan abu setelah pembakaran. Walaupun proses gasifikasi dapat berjalan secara kontinu namun belum bisa memisahkan gas dengan bottom ash secara langsung sehingga untuk membuang abu harus memberhentikan alat terlebih dahulu, tidak bisa dilakukan secara continu. Selain itu masalah berikutnya adalah adanya fly ash yang keluar bersama dengan gas sehingga menyebabkan gas yang dihasilkan tidak seluruhnya gas. Untuk menyempurnakan sistem gasifikasi sistem kontinu berbahan bakar tongkol jagung, perlu dirancang alat yang dapat memisahkan bottom ash dan fly ash.

Tujuan penelitian ini adalah merancang sistem pemisah bottom ash dan fly ash pada sistem gasifikasi kontinu, dimana pemisah fly ash akan menggunakan siklon dan untuk bottom ash akan menggunakan screw conveyor.

\section{Metodologi}

Pada penelitian ini akan dilakukan dua perancangan yaitu perancangan alat pemisah abu untuk bottom ash akan menggunakan screw conveyor dan perancangan pemisah fly ash akan menggunakan siklon.

\subsection{Perancangan screw conveyor}

Parameter yang dirancang adalah piringan conveyor/flight, poros dan daya motor. Perancangan screw conveyor ini mengacu pada screw conveyor catalogue and engineering manual yang disusun oleh Continental. Tahap pertama dalam merancang screw conveyor, adalah menentukan karakteristik tongkol jagung. Berdasarkan tabel 2 dari buku screw conveyor catalogue and engineering manual [6], karakteristik material tongkol jagung yang dicacah (corn cob, ground) adalah sebagai berikut: massa jenis:17 lbs/ $\mathrm{ft}^{3}$, Grup komponen: $1 \mathrm{~A}-1 \mathrm{~B}-1 \mathrm{C}$, Nomor kapasitas: 5, Faktor daya (F): 0,6 dimana penjelasan grup komponen, faktor daya dan kapasitas berdasarkan tabel 1 buku tersebut adalah untuk screw conveyor ini menggunakan jenis pitch full pitch segments sehingga untuk pitch dari screw conveyor dibuat menjadi sepertiga dari diameter screw conveyor, untuk Panjang total dari screw conveyor dirancang sepanjang 1, 1 feet. Screw conveyor memiliki berbagai jenis piringan conveyor atau biasa disebut flight. Pada perancangan ini digunakan jenis flight sectional conveyor screws dengan half pitch segments. Dipilih tipe ini karena memang cocok untuk mengantarkan bottom ash keluar dari alat serta dapat mempercepat keluarnya bottom ash. Untuk proses pembuatannya juga relatif lebih mudah. Pada perancangan screw conveyor asumsi yang digunakan yaitu kapasitas yang masuk ke screw conveyor pembuang abu sama dengan debit yang masuk pada screw conveyor pengumpan yaitu $6 \mathrm{~kg} / \mathrm{jam}$ atau 0,705 $\mathrm{ft}^{3} / \mathrm{jam}$, sehingga putaran screw diperoleh $0,31 \mathrm{rpm}$ dan dari tabel diperoleh diameter screw conveyor 6 inci, Nomor helicodial: 6H304, nomor sectional: 6S309, ketebalan cover 16 ga (setara dengan $1,59 \mathrm{~mm}$ ), termasuk normal service.

Dari tabel tersebut diperoleh juga bearing yang dapat yang digunakan, yaitu jenis ball bearing, wood bearing dan babbitted bearing. Dipilih jenis ball bearing karena lebih mudah didapatkan dan harga yang cukup murah. Nomor helicodial dan nomor sectional merupakan semacam kode untuk memudahkan menentukan spesifikasi dari screw conveyor. Angka pertama menunjukkan diameter screw conveyor, huruf kedua menunjukkan jenis screw conveyor, angka ketiga menujukkan diameter kopling, dan dua angka terakhir menunjukkan ketebalan dari flight. Pada perancangan screw conveyor, panjang yang akan dibuat sepanjang $33 \mathrm{~cm}$, atau sekitar $1.1 \mathrm{ft}$. Daya conveyor diperoleh melalui persamaan (1) dibawah ini:

Daya $=\frac{\mathrm{L}[(\mathrm{D} \times \mathrm{S})+(\mathrm{Q} \times \mathrm{F})]}{1000000}=\frac{1,1[(18 \times 0,31)+(12 \times 0,6)]}{1000000}=0,000013 \mathrm{HP}[6]$

Dimana:

$\mathrm{L}=$ Panjang total conveyor $(\mathrm{ft})$

$\mathrm{D}=$ Friction factor

$\mathrm{S}=$ Kecepatan conveyor (rpm) 
$\mathrm{Q}=$ Kuantitas material ( $\mathrm{lbs} / \mathrm{jam})$

$\mathrm{F}=$ Horse power factor.

Nilai D adalah nilai faktor untuk gesekan pada bantalan. Nilai D didapat dari data diameter screw conveyor dan tipe bearing yang digunakan. Untuk bearing yang digunakan adalah jenis ball bearing[6].

Dari dua data tersebut didapat nilai D yaitu 18. Dari data konversi daya, motor listrik yang dapat digunakan adalah motor listrik dengan kapasitas $1 \mathrm{HP}$. Motor listrik dengan daya $1 \mathrm{HP}$ secara umum akan menghasilkan putaran sebesar $1400 \mathrm{rpm}$. Dalam perhitungan didapatkan putaran pada screw conveyor sebesar $0,31 \mathrm{rpm}$. Jika dari putaran motor listrik diubah menjadi $0,31 \mathrm{rpm}$ maka hal ini mustahil, karena akan membutuhkan reduksi yang sangat banyak. Oleh karena itu pada perancangan ini putaran dari motor listrik ke screw conveyor direduksi menjadi $700 \mathrm{rpm}$. Perubahan ini tidak terlalu membuat masalah karena hanya membuat waktu pembuangan bottom ash menjadi lebih cepat.

Diameter poros diperoleh dari grafik hubungan antara motor listrik dan putaran konveyor pada tabel 8 buku screw conveyor catalogue and engineering manual [6], diperoleh diameter poros sebesar 2 inci. Hasil perancangan screw conveyor diperlihatkan pada gambar 2 berikut :

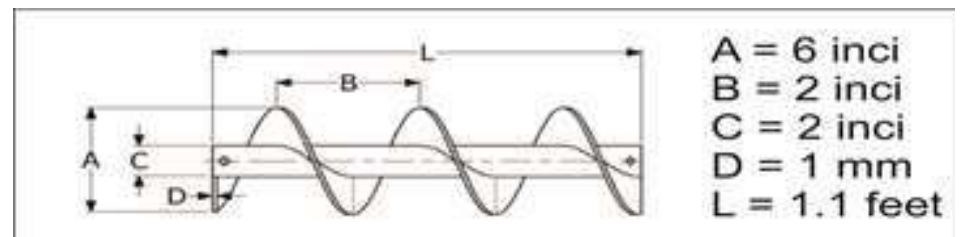

Gambar 2. Dimensi screw conveyor

\subsection{Perancangan siklon}

Siklon dirancang menggunakan standar lappe yaitu siklon secara konvesional. Dipilih siklon secara konvensional karena perancangan ini dikhususkan hanya untuk dapat memisahkan fly ash dengan gas sehingga tidak mengejar nilai efisiensi yang tinggi. Dimensi standar siklon diberikan pada gambar dibawah ini [7].

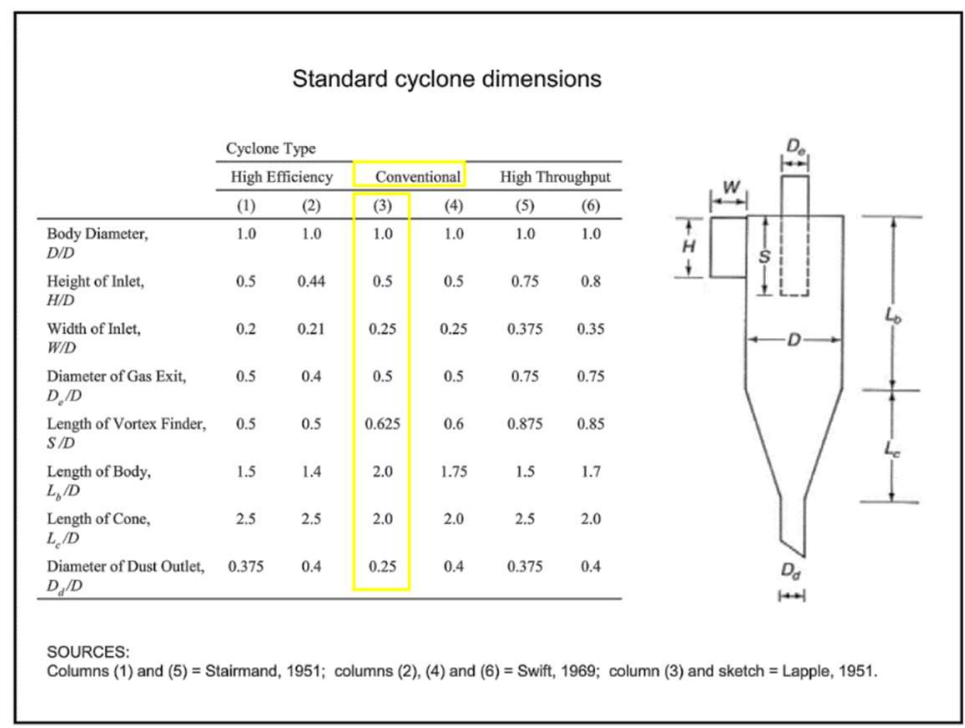

Gambar 3. Standar dimensi siklon [7] 
Diasumsikan diameter siklon adalah $0,1 \mathrm{~m}$ maka dimensi siklon hasil perancangan seperti ditunjukan pada Tabel 1. dan Gambar 4. sebagai berikut:

Tabel 1. Dimensi siklon

\begin{tabular}{|l|c|c|r|}
\hline \multicolumn{1}{|c|}{ Keterangan } & Simbol & rasio & $\begin{array}{c}\text { Ukuran } \\
(\mathrm{m})\end{array}$ \\
\hline $\begin{array}{l}\text { Diameter cyclone Body } \\
\text { (Barrel) }\end{array}$ & $\mathrm{D}$ & $\mathrm{D}$ & 0,1 \\
\hline Length of the Body & $\mathrm{Lb}$ & 2D & 0,2 \\
\hline Length of the Cone & $\mathrm{Lc}$ & 2D & 0,2 \\
\hline Height of the Inlet & $\mathrm{H}$ & $\mathrm{D} / 2$ & 0,05 \\
\hline Width of the Inlet & $\mathrm{W}$ & $\mathrm{D} / 4$ & 0,025 \\
\hline Diameter of Gas Exit & $\mathrm{De}$ & $\mathrm{D} / 2$ & 0,05 \\
\hline Diameter of Dust outlet & $\mathrm{Dd}$ & $\mathrm{D} / 4$ & 0,025 \\
\hline Length of vortex Finder & $\mathrm{S}$ & $0,625 \mathrm{D}$ & 0,0625 \\
\hline Length of Sc & $\mathrm{Sc}$ & $\mathrm{D} / 8$ & 0,0125 \\
\hline Total length of cyclone & $\mathrm{Lb}+\mathrm{Lc}$ & $4 \mathrm{D}$ & 0,4
\end{tabular}

\subsection{Simulasi pengujian}

Simulasi menggunakan software Ansys untuk melihat pergerakan partikel di dalam siklon dan mencari efisiensi siklon yang mendekati sebenarnya. Mesh ukuran yang digunakan berbentuk kotak dengan $2.4226 \times 10^{-2} \mathrm{~m}$. Assumsi yang diterapkan antara lain; steady state, pressure base/siklon bekerja berdasarkan tekanan, kecepatan dalam siklon tidak berubah-ubah. Pada kecepatan diinputkan kecepatan sisi masuk udara pada siklon yaitu $37.608 \mathrm{~m} / \mathrm{s}$. Kecepatan ini didapat dari perhitungan siklon saat mencari efisiensi siklon. Total flow rate dibiarkan saja di angka $1 \mathrm{e}-20 \mathrm{~kg} / \mathrm{s}$, karena untuk saat ini tidak memperhitungkan flow rate, massa jenis partikel diinputkan $232 \mathrm{~kg} / \mathrm{m}^{3}$ [8].

Boundary conditions yang diinputkan pada sisi inlet adalah velocity-inlet karena pada sisi masuk yang ditinjau adalah kecepatan gas. Pada bagian momentum, velocity magnitude menjadi 37.608 $\mathrm{m} / \mathrm{s}$, pada bagian turbulent, untuk specification method diganti menjadi intensity and hydraulic diameter.

Untuk turbulen dipilih intensity and hydraulic diameter karena sisi masuk siklon tidak berbentuk lingkaran, untuk turbulen intensity 5\% karena diasumsikan di dalam siklon aliran turbulen sangat kecil. Pada hydraulic diameter di set $0,033 \mathrm{~m}$ berdasarkan hasil perhitungan menggunakan persamaan (2), hydraulic diameter merupakan istilah yang umum digunakan ketika menangani aliran di saluran yang tidak berbentuk lingkaran.

$\mathrm{D}_{\mathrm{h} \text { inlet }}=\frac{4 \mathrm{~A}}{\mathrm{P}}=\frac{4 \times(\mathrm{p} \times \mathrm{l})}{2 \times(\mathrm{p}+\mathrm{l})}=\frac{2 \times(\mathrm{p} \times \mathrm{l})}{(\mathrm{p}+\mathrm{l})}=\frac{2 \times(0,05 \mathrm{~m} \times 0,025 \mathrm{~m})}{(0,05 \mathrm{~m}+0,025 \mathrm{~m})}=0,033 \mathrm{~m}$

Pada sisi keluar dipilih pressure-outlet karena pada sisi keluar lebih ditinjau tekanan. Pada bagian momentum, gauge pressure menjadi 0 pascal. Kemudian pada bagian turbulent, untuk specification method menjadi intensity and hydraulic diameter karena untuk input datanya lebih mudah dibandingkan opsi yang lain. Untuk turbulen intensity menjadi 5\% diasumsikan di dalam siklon aliran turbulen sangat kecil. Untuk hydraulic diameter diubah menjadi 0,05 m. karena saluran outlet gas sudah berbetuk lingkaran, maka untuk hydraulic diameter akan sama dengan diameternya yaitu $0,05 \mathrm{~m}$. Jumlah iterasi di set 5000 


\section{Hasil Dan Pembahasan}

Hasil simulasi diperlihatkan pada gambar 5. Saat simulasi berjalan dapat dilihat partikel-partikel yang bergerak. Partikel ini digambarkan sebagai bola oleh software B6: fluid flow (fluent). Disini dapat dilihat mana partikel yang akan terus keatas dengan partikel yang akan jatuh kebawah. Pada hasil simulasi terdapat legenda dengan berbagai warna, warna tersebut menyatakan posisi partikel pada waktu tertentu. Untuk setiap partikel memiliki range waktu yang berbeda.

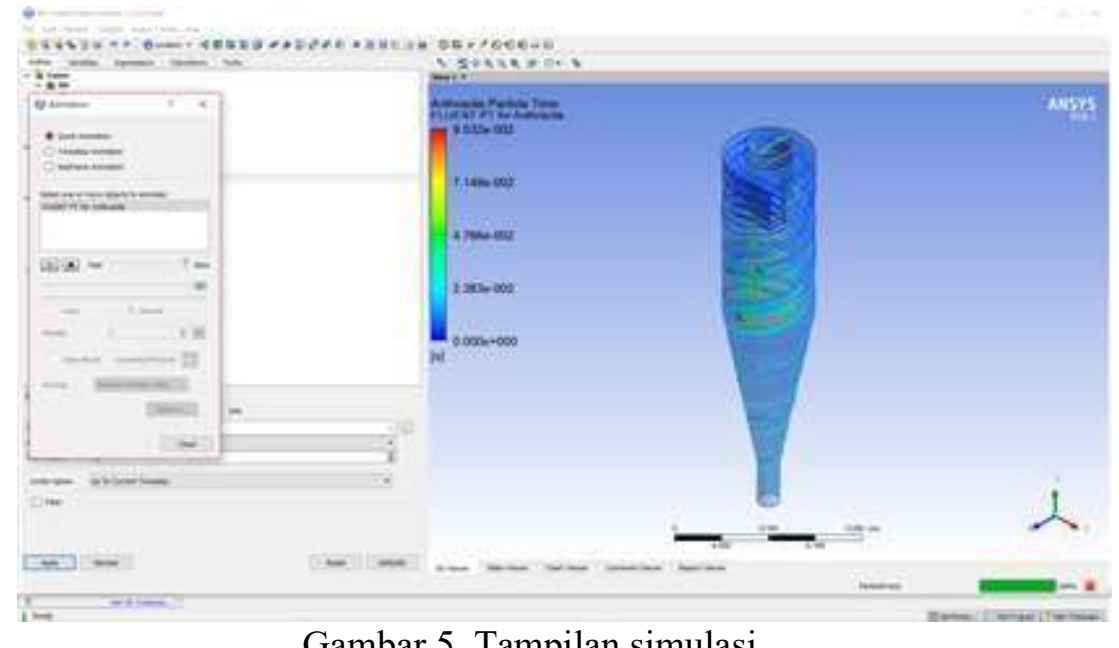

Gambar 5. Tampilan simulasi

Pada simulasi siklon ini, distribusi partikel dari abu dibagi menjadi 3 bagian. Bagian yang pertama distribusi partikel dari 0,5 mikron meter hingga 1 mikron meter. Bagian yang kedua distribusi partikel dari 2 mikron meter hingga 7 mikron meter. Dan untuk yang ketiga distribusi partikel dari 8 mikron meter hingga 40 mikron meter [8].

Pada pembagian yang pertama, yaitu distribusi partikel dari 0,5 mikron meter hingga 1 mikron meter, diambil diameter rata-rata yaitu 0,75 mikron meter. Pada saat simulasi berlangsung, terdapat 15 partikel yang masuk kedalam siklon. Seiring berputarnya partikel, terdapat 10 partikel yang terus menuju ke bagian bawah siklon sedangkan terdapat 5 partikel yang lolos keluar keatas ikut bersama gas. Gambar 6 menunjukan distribusi partikel bagian pertama

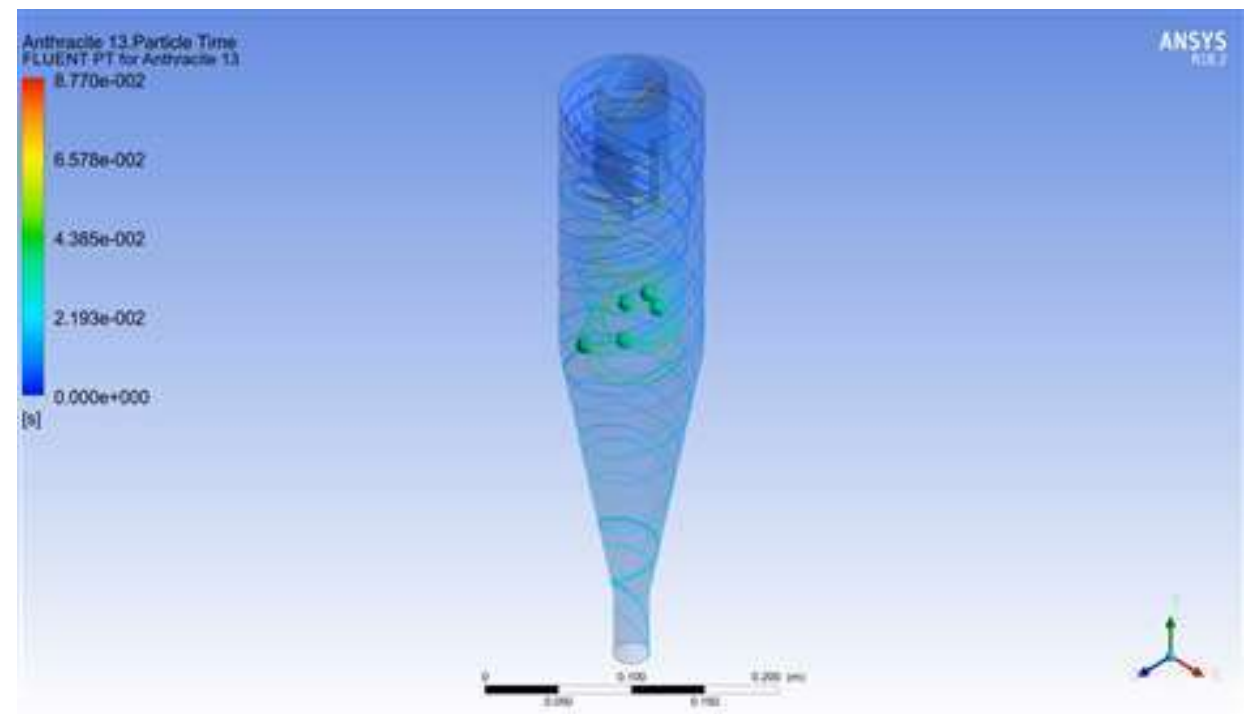

Gambar 6. Simulasi pada diameter partikel 0,75 mikron meter 
Pada bagian yang kedua yang diperlihatkan pada gambar 7 yaitu distribusi partikel dari 2 mikron meter hingga 7 mikron meter, diambil diameter rata-rata yaitu 4.5 mikron meter. Pada saat simulasi berlangsung, terdapat 15 partikel yang masuk kedalam siklon. Seiring berputarnya partikel, terdapat 11 partikel yang terus menuju ke bagian bawah siklon sedangkan terdapat 4 partikel yang lolos keluar keatas ikut bersama gas.

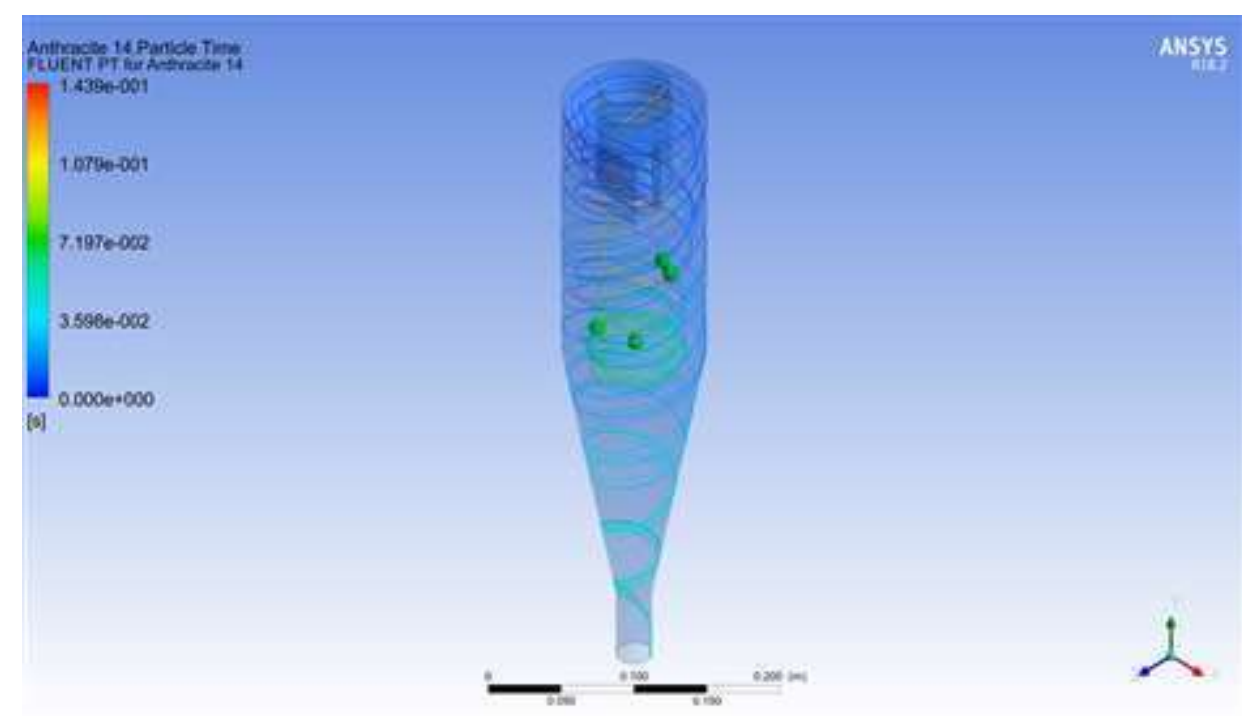

Gambar 7. Simulasi pada diameter partikel 4.5 mikron

Pada pembagian yang ketiga seperti yang diperlihatkan pada gambar 8 yaitu distribusi partikel dari 8 mikron meter hingga 40 mikron meter, diambil diameter rata-rata yaitu 19.5 mikron meter. Pada saat simulasi berlangsung, terdapat 15 partikel yang masuk kedalam siklon. Seiring berputarnya partikel, terdapat 14 partikel yang terus menuju ke bagian bawah siklon sedangkan terdapat 1 partikel yang secara simulasi dinyatakan incomplete. Dinyatakan incomplete karena pergerakan partikel terus berputar-putar dalam satu lintasan sehingga membutuhkan simulasi yang lebih lama lagi untuk mendapatkan hasilnya.

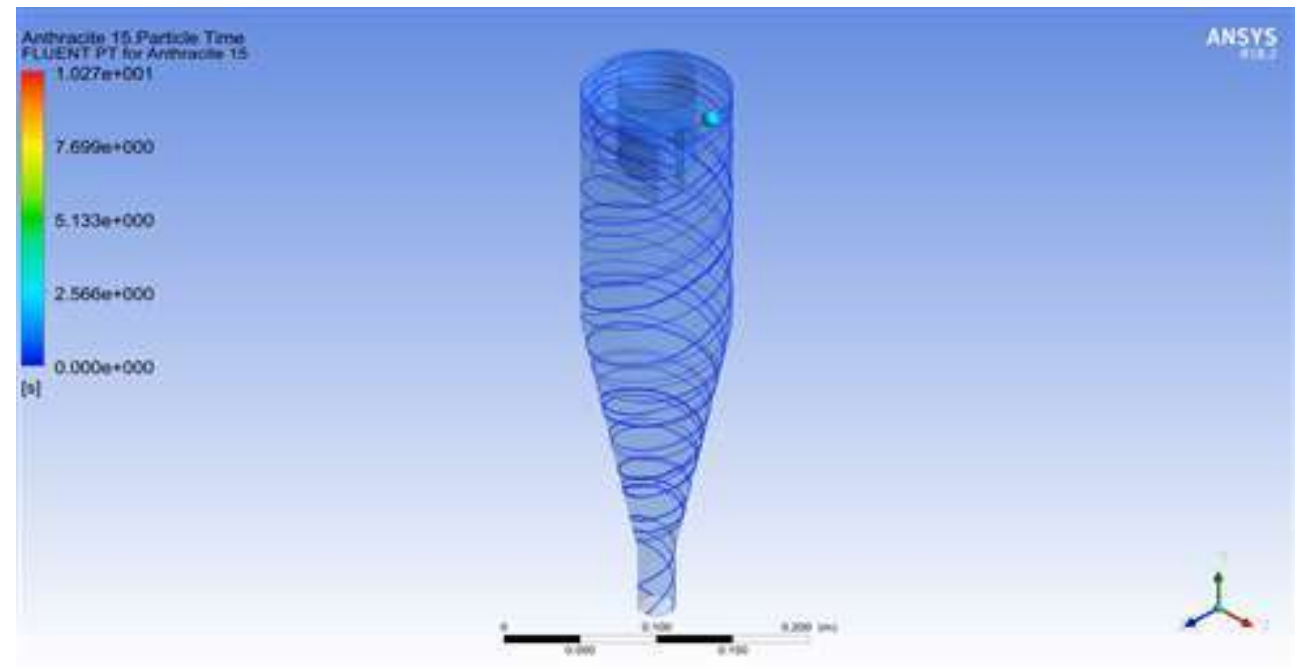

Gambar 8. Hasil pada diameter partikel 19.5 mikron meter

Dari simulasi juga dapat dihitung efisiensi dari siklon untuk beberapa ukuran partikel dengan menggunakan persamaan (3)

$\eta_{\text {siklon }}=\frac{n_{\text {particle trapped }}}{n_{\text {particle injected }}-n_{\text {particle incomplete }}}$ 
Dimana $n_{\text {particle trapped }}$ adalah jumlah partikel yang terbuang, $n_{\text {particle injected }}$ jumlah partikel

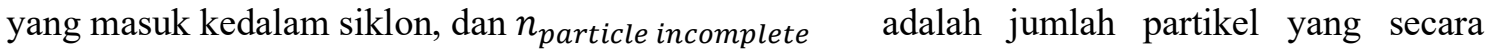
simulasi tidak dapat diselesaikan. Efisiensi berdasarkan simulasi diperlihatkan pada gambar 9.

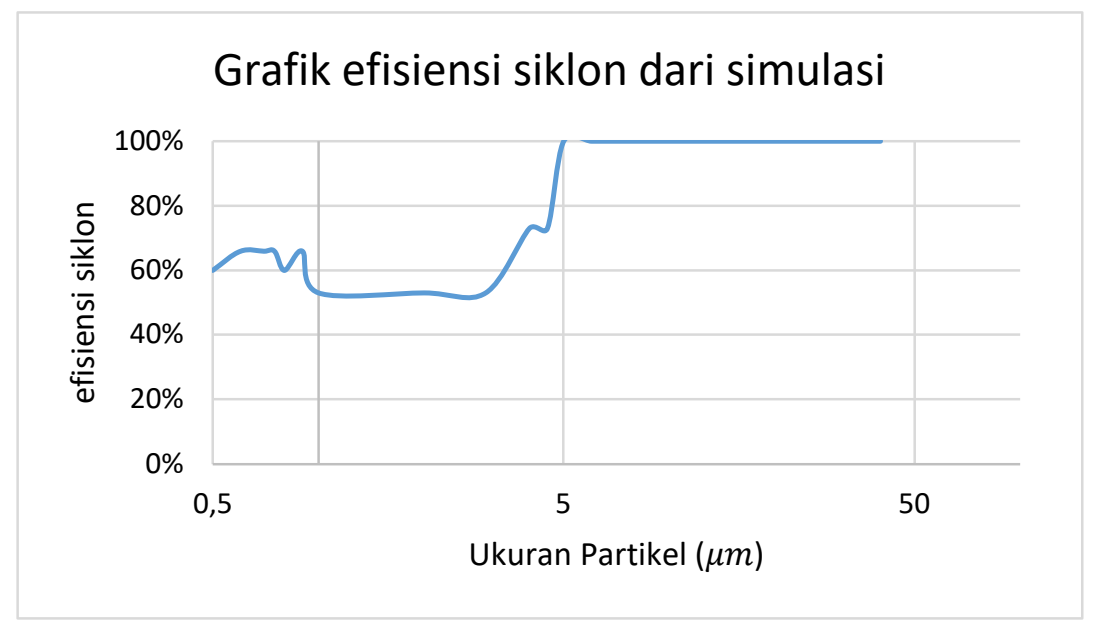

Gambar 9. Grafik efisiensi siklon berdasarkan simulasi

Efisiensi siklon yang didapat dari simulasi sebesar $80,4 \%$. Dari nilai efisiensi oleh simulasi, saat partikel masuk kedalam siklon tidak akan semua partikel terbuang oleh siklon tetapi masih ada yang akan terbawa oleh gas.

Dari grafik pada gambar 9 terlihat terdapat 2 kali penurunan efisiensi siklon. Penurunan pertama adalah pada saat dari partikel $0,75 \mu \mathrm{m}$ menuju $0,8 \mu \mathrm{m}$ sebesar $6 \%$ dan dari partikel $0,9 \mu \mathrm{m}$ menuju $1 \mu \mathrm{m}$ sebesar 13\%. Diharapkan saat ukuran partikel semakin besar maka efisiensi siklon untuk memisahkan fly ash semakin besar, namun tidak terjadi pada pergerakan partikel yang sudah disebutkan.

Efisiensi hasil simulasi akan dibandingkan dengan efisiensi hasil perhitungan. Parameterparameter yang dibutuhkan untuk menghitung efisiensi diantaranya; jumlah putaran gas saat berada di dalam siklon (The number of effective turns) persamaan (4).

$$
N_{e}=\frac{1}{H}\left(L_{b}+\frac{L_{b}}{2}\right), N_{e}=\frac{1}{0,05 m}\left(0,2 m+\frac{0,2 m}{2}\right)=6
$$

Diameter minimum (Cut point diameter) dimana siklon mampu menghasilkan efisiensi sebesar $50 \%$ persamaan $(5)$

$d_{p c}=\sqrt{\frac{9 \mu W}{2 \pi N_{e} V_{i}\left(\rho_{p}-\rho_{g}\right)}}=3,55 \times 10^{-6} \mathrm{~m}$

Waktu yang dibutuhkan gas untuk dapat keluar dari siklon (Gas residence time) persamaan (6),

$$
\Delta t=\frac{\pi D N_{e}}{V_{i}}=0,05012 \mathrm{~s}
$$

Kecepatan partikel searah sumbu radial (Particle drift velocity) persamaan 7.

$$
V_{t}=\frac{W}{\Delta t}=0,4987 \frac{m}{s}
$$

Untuk partikel berukuran $0,0000005 \mathrm{~m}$, maka nilai $\mathrm{D}_{\mathrm{pj}}=0,0000005 \mathrm{~m}$ dan terdapat kandungan $1,25 \%$ dalam total fly ash. Maka efisiensi yang dapat dihasilkan oleh siklon berdasarkan diameter partikel yang akan dipisah atau Fractional efficiency melalui persamaan 8 adalah 
$\eta_{j}=\frac{1}{1+\left(\frac{D_{p c}}{D_{p j}}\right)^{2}}=\frac{1}{1+\left(\frac{3,55 \times 10^{-6} m}{0,0000005 \mathrm{~m}}\right)^{2}}=0,0194209$

Selanjutnya dihitung efisiensi untuk variasi ukuran partikel yang lain dengan cara yang sama, sehingga diperoleh efisiensi seperti grafik pada gambar 10 berikut

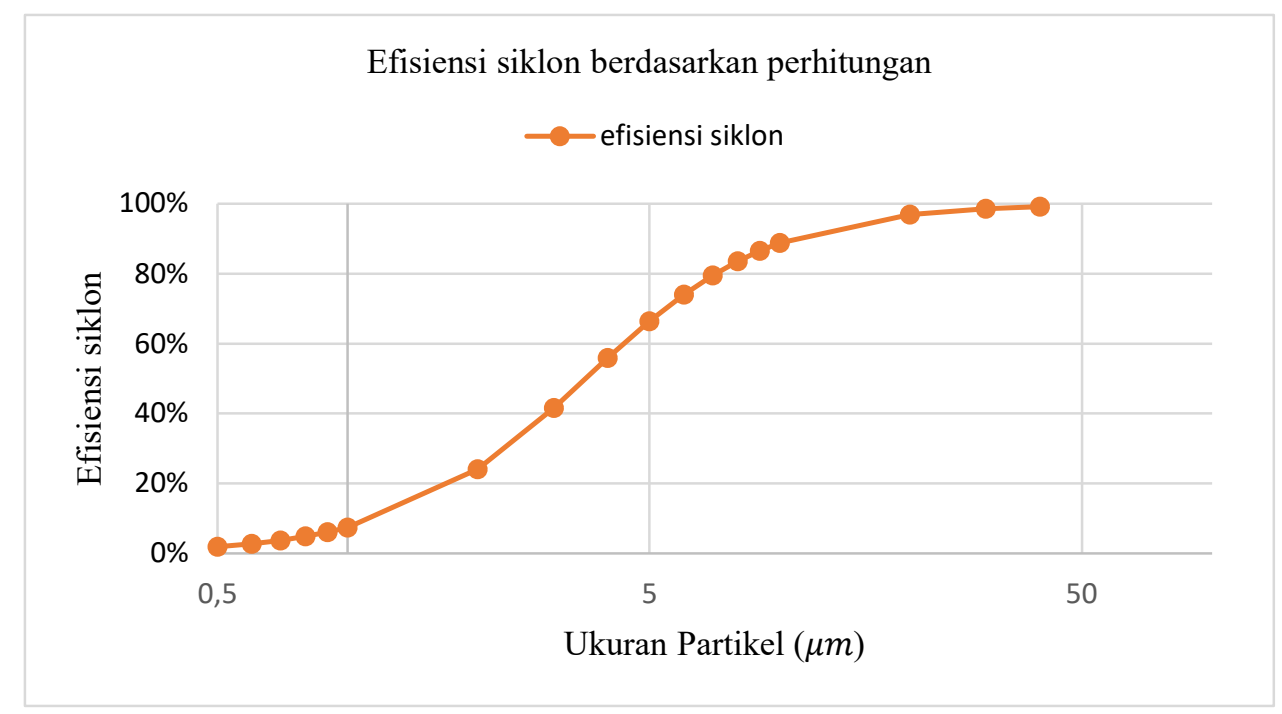

Gambar 10. Grafik efisiensi berdasarkan perhitungan

Efisiensi siklon yang didapat dari perhitungan sebesar 78,52\% sehingga menandakan bahwa tidak semua partikel yang masuk kedalam siklon akan terbuang, tetapi sebagian akan terbawa oleh gas.

Pada grafik efisiensi siklon dari simulasi terilhat berbeda dengan grafik efisiensi siklon secara perhitungan. Hal ini terjadi karena pada simulasi banyak data-data yang digunakan menyerupai dengan kondisi aslinya sehingga perhitungannya akan berbeda dengan penggunaan rumus biasa. Selain itu jika ada perbedaan input data maka hasil dari simulasi juga akan berbeda. Input data yang dapat diubah ialah ukuran mesh, max number of steps, nilai tolerance, velocity magnitude, total flow rate, massa jenis, dan boundary conditions untuk setiap sisi. Ukuran mesh yang digunakan untuk simulasi adalah $2.4226 \times 10^{-2} \mathrm{~m}$. Jika ukuran mesh ini dibuat lebih kecil maka proses simulasi akan menjadi lebih akurat lagi. Tetapi jika ukuran mesh diperbesar kemungkinan hasil simulasi tidak akan terlalu akurat.

Selain efisiensi, dari simulasi dapat diperoleh range waktu pergerakan partikel di dalam siklon dari berbagai ukuran partikel, seperti yang diperlihatkan pada grafik pada gambar 11

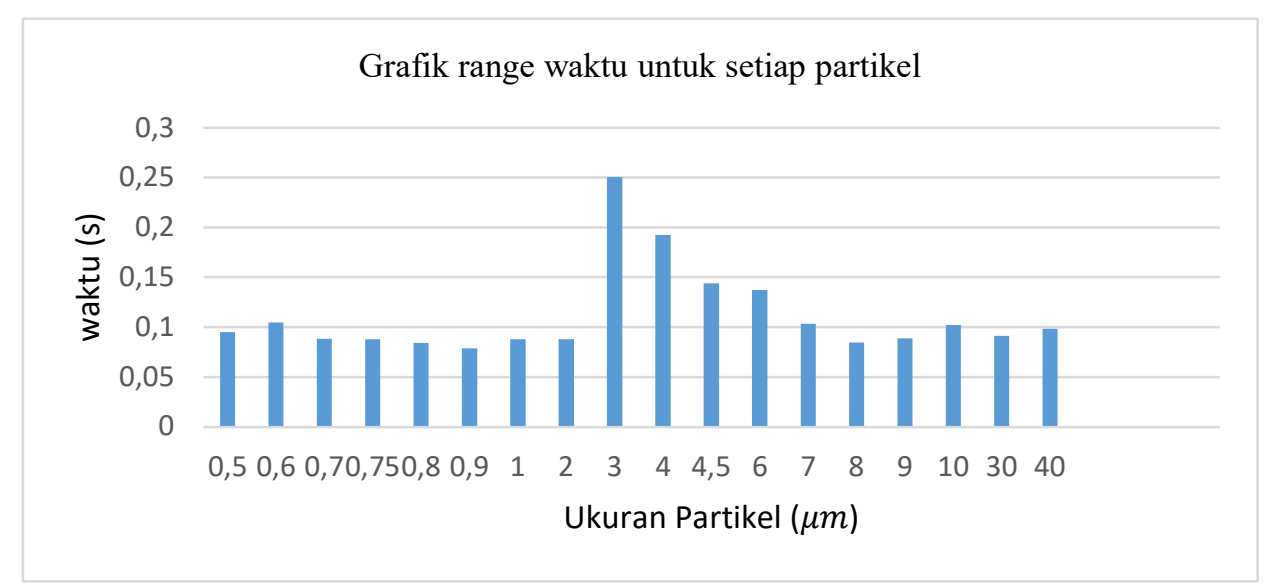

Gambar 11. Grafik range waktu untuk setiap partikel 
Dari grafik pada gambar 11 dapat terlihat range waktu pergerakan partikel relatif normal. Hanya terdapat waktu tertinggi yang dapat dicapai adalah sebesar 0.25 detik untuk partikel berukuran 3 $\mu m[8]$.

\section{Kesimpulan}

Hasil perancangan diperoleh spesifikasi yang dibutuhkan yaitu diameter screw sebesar 6 inci, motor listrik yang digunakan memiliki daya $1 \mathrm{HP}$, putaran screw sebesar $0,31 \mathrm{rpm}$ dan poros screw conveyor sebesar 2 inci. Dengan standar yang sudah diberikan, dengan mengasumsikan diameter body siklon sebesar $0,1 \mathrm{~m}$ maka diperoleh seluruh dimensi siklon. Dengan diameter sebesar $0,1 \mathrm{~m}$ secara perhitungan didapat efisiensi siklon sebesar $78 \%$ dan secara simulasi menggunakan software ANSYS didapat efisiensi sebesar 80\%.

Dari hasil perhitungan didapat bahwa semakin besar ukuran partikel maka semakin mudah partikel terpisah dengan gas. Tetapi jumlah partikel juga mempengaruhi efisiensi siklon. Dari simulasi pergerakan partikel di dalam siklon dapat dilihat bahwa semakin besar ukuran partikel maka akan semakin mudah partikel dan gas terpisah.

\section{Notasi}

$\mathrm{D}_{\mathrm{h}} \quad$ hydraulic diameter $\quad[\mathrm{m}]$

$\mathrm{P} \quad$ keliling penampang saluran $\quad[\mathrm{m}]$

$\eta_{j} \quad$ efisiensi berdasarkan partikel

$\Delta t \quad$ waktu yang dibutuhkan gas untuk keluar siklon $\quad[\mathrm{s}]$

$\mathrm{V}_{\mathrm{i}}$ kecepatan gas masuk $\quad[\mathrm{m} / \mathrm{s}]$

$\mathrm{D}_{\mathrm{pc}} \quad$ diameter minimum partikel $\quad[\mathrm{m}]$

$\mu$ viskositas gas [kg.m/s]

$\mathrm{N}_{\mathrm{e}} \quad$ jumlah putaran

\section{Daftar Pustaka}

[1]. Higman, Christopher. 2003. Gasification. Gulf Professional Publishing, Netherlands

[2]. Rezaiyan, Jhon. 2005. Gasification Technologies: A Primer for Engineer and Scientist. Taylor and Francis Group, USA.

[3]. Sulaiman, Andi Amran. 2017. Cara Cepat Swasembada Jagung. Jakarta: Sekretariat Jendral Kementrian Pertanian RI

[4]. Alkuino E.L. 2000. Gasifying farm wastes as source of cheap heat for drying paddy and corns. International Rice Research Organisation. Philipines.

[5]. M. Pramuda S.T., M.T. 2010. Pembuatan Prototipe Gasifier Sistem Kontinu Berbahan Bakar Tongkol Jagung [Tesis]. Bandung (ID): Institut Teknologi Bandung

[6]. Continental. 1986. Screw Conveyor Catalouge and Engineering Manual. Canada: Continental.

[7]. Bashir, K. .2015. Design and fabrication of cyclone separator. 10-30.

[8]. B. Hadiwijaya. 2018. Perancangan Alat Pembuangan Abu Pada Gasifier Sistem Kontinu Berbahan Bakar Tongkol Jagung [Skripsi]. Bandung (ID). Institut Teknologi Nasional. 